\title{
Pengaruh Inisiasi Menyusu Dini (IMD) terhadap Suhu dan Kehilangan Panas pada Bayi Baru Lahir
}

\author{
Hotma Sauhur Hutagaol ${ }^{1}$, Eryati Darwin ${ }^{2}$, Eny Yantri ${ }^{3}$
}

\begin{abstract}
Abstrak
Hipotermia merupakan penyebab utama kesakitan dan kematian bayi baru lahir di negara berkembang. Salah satu asuhan untuk mencegah hipotermi adalah dengan melaksanakan Inisiasi Menyusu Dini (IMD). Tujuan penelitian ini adalah untuk mengetahui pengaruh inisiasi menyusu dini terhadap suhu aksila dan kehilangan panas kering pada bayi baru lahir. Ini merupakan studi cross-sectional comparative yang melakukan observasi bayi yang lahir dengan persalinan normal yang dilaksanakan IMD atau tidak, kemudian dilakukan pengukuran suhu aksila dan kehilangan panas kering pada kedua kelompok. Data dianalisa menggunakan uji t-test, dan nilai $p<0.05$ dianggap bermakna secara statistik. Rerata suhu aksila kelompok IMD sebesar $37,1 \pm 0,2^{0} \mathrm{C}$ dan rerata suhu aksila pada kelompok non IMD sebesar $36,8 \pm 0,4^{\circ} \mathrm{C}$. Rerata total kehilangan panas kering pada kelompok IMD sebesar 30,1 $\pm 3,4 \mathrm{~J}$ dan pada kelompok non IMD sebesar 31,2 \pm 3,9 J. Hasil penelitian menyimpulkan bahwa IMD berpengaruh terhadap peningkatan suhu aksila. Kehilangan panas kering lebih rendah pada kelompok IMD walau tidak bermakna secara statistik
\end{abstract}

Kata kunci: IMD, suhu aksila, kehilangan panas kering

\begin{abstract}
Hypothermia is a major cause of morbidity and mortality in neonatal period. One of essential care for newborn to prevent hypothermia is early initiation of breastfeeding. The objective of this study was to see the effects of early initiation of breastfeeding to increase axillary temperature and decrease dry heat loss in newborn. The design of this study is observational study with cross-sectional comparative design. The subjects were normal newborn with early initiation of breastfeeding and without early initiation of breastfeeding. Axillary mean temperature after early initiation of breastfeeding is $37,1 \pm 0,2^{\circ} \mathrm{C}$ and axillary mean temperature on non early initiation of breastfeeding group is $36,8 \pm$ $0,4^{\circ} \mathrm{C}$. Total dry heat loss mean on early initiation of breastfeeding group is 30,1 $\pm 3,4 \mathrm{~J}$ and on non early initiation of breastfeeding group is 31,2 $\pm 3,9 \mathrm{~J}$. This study concluded that there is the effect of early initiation of breastfeeding to axillary temperature. Total dry heat loss is lower on early initiation of breastfeeding group but not significant statistically.
\end{abstract}

Keywords: early initiation of breastfeeding, axillary temperature, dry heat loss

Affiliasi penulis : 1. Program Studi Magister Kebidanan Fakultas Kedokteran Universitas Andalas Padang, 2. Bagian Histologi FK UNAND, 3. Bagian Anak FK UNAND/RSUP Dr. M. Djamil Padang Korespondensi : Hotma Sauhur Hutagaol, email: rut4jc@yahoo.com, Telp: 081263596002

\section{PENDAHULUAN}

Bayi baru lahir kehilangan panas empat kali lebih besar dari pada orang dewasa, sehingga mengakibatkan terjadinya penurunan suhu. Pada 30 menit pertama bayi dapat mengalami penurunan suhu $3-4^{\circ} \mathrm{C}$. Pada ruangan dengan suhu $20-25^{\circ} \mathrm{C}$ suhu kulit bayi turun sekitar $0,3^{\circ} \mathrm{C}$ per menit. Penurunan suhu diakibatkan oleh kehilangan panas secara konduksi, konveksi, evaporasi dan radiasi. Kemampuan bayi yang belum sempurna dalam memproduksi panas maka bayi sangat rentan untuk mengalami hipotermia. $^{1}$

Hipotermia merupakan penyebab utama kesakitan dan kematian bayi baru lahir di negara berkembang. Prevalensi yang tinggi dari hipotermia 
telah dilaporkan secara luas bahkan dari negara tropis. WHO telah merekomendasikan asuhan untuk mempertahankan panas dalam asuhan bayi baru lahir, namun hipotermia terus berlanjut menjadi kondisi yang biasa terjadi pada neonatal, yang tidak diketahui, tidak di dokumentasikan dan kurang memperoleh penanganan. $^{2}$

Suhu bayi yang rendah mengakibatkan proses metabolik dan fisiologi melambat. Kecepatan pernafasan dan denyut jantung sangat melambat, tekanan darah rendah dan kesadaran menghilang. Bila keadaan ini terus berlanjut dan tidak mendapatkan penanganan maka dapat menimbulkan kematian pada bayi baru lahir. ${ }^{3,4}$

Resiko kematian pada bayi baru lahir tinggi pada saat kelahiran dan semakin menurun pada hari dan minggu berikutnya. Sekitar 50\% kematian bayi terjadi dalam 24 jam pertama kelahiran dan sekitar $75 \%$ terjadi selama minggu pertama kelahiran. Kematian bayi dikenal dengan fenomena 2/3, pertama, fenomena $2 / 3$ kematian bayi pada bulan pertama, $2 / 3$ kematian bayi pada 1 minggu pertama dan 2/3 kematian bayi pada 24 jam pertama. ${ }^{5}$

Hipotermia cenderung terjadi pada masa transisi pada bayi baru lahir. Masa transisi bayi merupakan masa yang sangat kritis pada bayi dalam upaya untuk dapat bertahan hidup. Bayi baru lahir harus beradaptasi dengan kehidupan di luar uterus yang suhunya jauh lebih dingin bila dibandingkan suhu didalam uterus yang relatif lebih hangat sekitar $37^{\circ} \mathrm{C}$. Suhu ruangan yang normalnya $25^{\circ} \mathrm{C}-27^{\circ} \mathrm{C}$ berarti ada penurunan sekitar $10^{\circ} \mathrm{C}$. Kemampuan bayi baru lahir tidak stabil dalam mengendalikan suhu secara adekuat, bahkan jika bayi lahir saat cukup bulan dan sehat sehingga sangat rentan untuk kehilangan panas. $^{6,7}$

Asuhan essensial diperlukan pada bayi baru lahir agar dapat mencegah terjadinya komplikasi dan dapat menyelamatkan nyawa bayi seperti segera mengeringkan tubuh bayi baru lahir dan inisiasi menyusu dini sangat diperlukan untuk upaya bayi dapat bertahan hidup dan menunda semua asuhan lainnya minimal satu jam pertama kelahiran. ${ }^{8}$

Inisiasi Menyusu Dini (IMD) adalah proses bayi menyusu segera setelah dilahirkan dengan air susu ibunya sendiri dalam satu jam pertama kelahiran.
Tujuan penelitian ini adalah untuk mengetahui pengaruh hubungan inisiasi menyusu dini terhadap suhu dan kehilangan panas pada bayi baru lahir.

\section{METODE}

Penelitian ini merupakan suatu penelitian observasional dengan disain cross-sectional comparatif untuk mengetahui pengaruh IMD terhadap suhu dan kehilangan panas pada bayi baru lahir. Tempat penelitian adalah di ruang bersalin RS Tk. III Dr. Reksodiwiryo Padang. Waktu penelitian dilakukan selama 6 (enam) bulan.

Populasi penelitian ini adalah semua bayi baru lahir normal di RS Tk.III Dr. Reksodiwiryo Padang Sumatera Barat. Subjek penelitian yang dipilih adalah semua populasi yang memenuhi kriteria inklusi dan eksklusi. Kriteria inklusi dalam penelitian ini adalah bayi baru lahir spontan, normal dan bugar. Kriteria eksklusi adalah bayi demam, bayi dengan kelainan bawaan, bayi yang memiliki gangguan menelan/menyusui, terdapat mekonium pada cairan ketuban dengan presentasi kepala. Kelompok kontrol adalah ibu yang memenuhi kriteria inklusi tetapi menolak untuk melakukan inisiasi menyusu dini, ibu dengan masalah atau komplikasi pada kala tiga dan masa nifas sehingga tidak dapat melakukan inisiasi menyusu dini.

Jumlah sampel dihitung dengan menggunakan rumus perhitungan sampel dengan metode penelitian cross-sectional. Simpang baku kedua kelompok bayi baru lahir dengan dan tanpa kontak kulit adalah 0,8. ${ }^{9}$ Berdasarkan rumus tersebut, diperoleh jumlah sampel sebesar 18 orang, ditambah drop out $10 \%$ menjadi 20 orang.

Suhu aksila diukur menggunakan termometer aksila digital.Kehilangan panas kering pada bayi baru lahir yang terjadi secara konveksi, radiasi dan konduksi, diukur dengan menggunakan Persamaan Kehilangan Panas konveksi: ${ }^{10}$

\footnotetext{
$\mathrm{Jq}_{\text {konveksi }}=8,3 \mathrm{~V}^{0,5}\left(\mathrm{~T}_{\mathrm{s}}-\mathrm{T}_{\mathrm{a}}\right)$

Ket:

Jq konveksi $=$ kehilangan panas konveksi antara kulit dan lingkungan $(\mathrm{J})$
} 
$V=$ kecepatan angin $(\mathrm{m} / \mathrm{s})$ 8,3 = konstanta dimana seseorang berdiri berhadapan dengan tiupan udara

Ts = suhu kulit $\left({ }^{\circ} \mathrm{C}\right)$ Suhu kulit rata-rata diperoleh dengan persamaan: $0,07 \mathrm{~T}_{\text {Dahi }}+0,175 \mathrm{~T}_{\text {Batangtubuh }}+0,175 \mathrm{~T}_{\text {Dada }}+0,07$ $\mathrm{T}_{\text {Lengan }}+0,07 \mathrm{~T}_{\text {Bahu }}+0,05 \mathrm{~T}_{\text {tangan }}+0,2 \mathrm{~T}_{\text {betis }}+0,19 \mathrm{~T}_{\text {paha }}$

$\mathrm{Ta}=$ suhu udara $\left({ }^{0} \mathrm{C}\right)$

Kehilangan panas secara radiasi :

Jq radiasi $=e \sigma \operatorname{Ar}\left(\mathrm{T}_{\mathrm{s}}^{4}-\mathrm{T}_{\mathrm{w}}{ }^{4}\right)$

Ket:

$\mathrm{Jq}_{\text {radiasi }}=$ kehilangan panas melalui radiasi $(\mathrm{J})$

$\mathrm{Ar} \quad=$ luas daerah efektif permukaan tubuh yang melepaskan radiasi (Du bois) yaitu 0,725 (luas daerah permukaan tubuh orang dewasa yang melepaskan radiasi) $-0,195 \mathrm{Ar}=0,530 \mathrm{Ar} .{ }^{11}$

$\epsilon=$ emisivitas permukaan kulit, 0,99

$\sigma=$ konstanta Stefan - Boltzmann $\left(5,67 \times 10^{-8} \mathrm{~W} / \mathrm{m}^{2} \mathrm{~K}^{4}\right)$

$\mathrm{Ts}=$ suhu kulit dalam derajat absolute $(\mathrm{K})$

$\mathrm{Tw}=$ suhu dinding lingkungan dalam derajat absolute $(\mathrm{K})$

Kehilangan panas secara konduksi :

Jq konduksi $=\frac{k s k a}{k s+k a} \cdot \frac{\left(T_{2}-T_{1}\right)}{\Delta X}$

Ket :

$\mathrm{Jq}_{\text {konduksi }}=$ kehilangan panas secara konduksi $(\mathrm{J})$

$\mathrm{ks}=$ koefisien konduktivitas kulit $\left(0,2 \mathrm{~J} / \mathrm{sm}^{0} \mathrm{C}\right)$

$\mathrm{Ka}=$ koefisien konduktivitas udara $\left(0,023 \mathrm{~J} / \mathrm{sm}^{0} \mathrm{C}\right)$

$\mathrm{T}_{2}-\mathrm{T}_{1}=$ perbedaan suhu antara udara dan kulit $\left({ }^{0} \mathrm{C}\right)$

Kehilangan panas total

$J_{\text {total }}=J_{q}$ konveksi $+J_{q \text { konduksi }}+J_{q}$ radiasi

Alat ukur: Termoscope digital, Termometer infra merah digital, Flowmeter, Termometer dinding, nomogram duBois, papan pengukur panjang badan, timbangan berat badan bayi. Alat telah ditera oleh Dinas Perindustrian dan Perdagangan UPTD Balai Metrologi Provinsi Sumatera Barat.

Pengukuran yang dilakukan adalah pengukuran suhu aksila, suhu kulit, suhu udara, suhu dinding, kecepatan angin yang dilakukan segera setelah lahir dan satu jam setelah kelahiran. Berat badan dan panjang badan bayi diukur satu jam setelah kelahiran. Baik bayi yang dilaksanakan IMD maupun kontrol akan diberikan pakaian/bedung, dengan 1 lapis bedung, 1 lapis kain segitiga, 1 lapis tali dua dan 1 buah topi kain.

\section{HASIL}

Setelah dilakukan observasi, didapatkan sebanyak 40 orang bayi baru lahir yang memenuhi kriteria inklusi. 20 orang bayi baru lahir dengan inisiasi menyusu dini disebut sebagai kelompok IMD dan 20 orang bayi baru lahir tanpa inisiasi menyusu dini karena ibu menolak untuk dilakukan IMD atau memiliki komplikasi sehingga tidak dapat dilakukan IMD disebut sebagai kelompok non IMD.

Tabel 1. Karakteristik Responden

\begin{tabular}{lccc}
\hline \multicolumn{1}{c}{ Karakteristik } & $\begin{array}{c}\text { IMD } \\
\text { Rerata } \pm \\
\text { SD }\end{array}$ & $\begin{array}{c}\text { Non IMD } \\
\text { Rerata } \pm\end{array}$ & $\boldsymbol{p}$ \\
& SD & \\
\hline Berat Badan (BB) & $3,2 \pm 0,3$ & $3,1 \pm 0,3$ & $p>0,05$ \\
Panjang Badan (PB) & $48,8 \pm 2,1$ & $48,3 \pm 1,4$ & $p>0,05$ \\
Body Surface Area & $0,2 \pm 0,01$ & $0,2 \pm 0,01$ & $p>0,05$ \\
(BSA) & & & \\
Suhu Kulit & $36,4 \pm 0,3$ & $36,5 \pm 0,4$ & $p>0,05$ \\
Suhu Aksila & $36,6 \pm 0,4$ & $36,8 \pm 0,4$ & $p>0,05$ \\
\hline
\end{tabular}

Tabel 1 menunjukkan karakteristik fisik bayi baru lahir.Secara keseluruhan karakteristik responden yaitu rerata berat badan, rerata panjang badan, rerata luas permukaan tubuh atau body surface area, suhu kulit dan suhu aksila menunjukkan hasil yang tidak berbeda secara bermakna antara kelompok IMD dan kelompok non IMD. Hal ini memperlihatkan homogenitas antara kedua kelompok.

Karakteristik fisik bayi baru lahir dan faktor lingkungan area persalinan berpengaruh kepada penurunan suhu bayi baru lahir, dan penurunan suhu tubuh yang cepat dapat terjadi jika tidak segera dilakukan asuhan pencegahan kehilangan panas pada bayi baru lahir yaitu sekitar $0,1-0,3^{0} \mathrm{C}$ per menit. ${ }^{12}$

Berat badan dan luas permukaan tubuh meme-ngaruhi total kehilangan panas kering pada bayi baru lahir, dimana total kehilangan panas kering lebih tinggi pada bayi dengan berat badan lebih rendah dan luas permukaan tubuh yang rendah, dibandingkan dengan bayi baru lahir dengan berat badan lahir dan luas permukaan tubuh yang lebih besar. $^{13}$ 
Tabel 2. Pengaruh IMD Terhadap Rerata \pm SD Suhu Aksila

\begin{tabular}{llc}
\hline & $\begin{array}{c}\text { Rerata } \pm \text { SD } \\
\text { }\end{array}$ & J \\
& Jam Kelahiran & \\
\hline IMD & $37,1 \pm 0,2$ & 0,010 \\
Non IMD & $36,8 \pm 0,4$ & \\
\hline
\end{tabular}

Tabel 2 menunjukkan analisis pengaruh IMD terhadap suhu aksila pada bayi baru lahir. Setelah dilakukan IMD selama satu jam maka rerata suhu aksila pada kelompok IMD lebih tinggi dari pada kelompok non IMD. Pada penelitian ini didapatkan hasil bahwa setelah dilakukan IMD selama satu jam suhu aksila meningkat $0,4 \pm 0,3^{\circ} \mathrm{C}$ sedangkan pada kelompok non IMD selama satu jam kelahiran hanya terdapat peningkatan suhu $0,03 \pm 0,3^{\circ} \mathrm{C}$. Pada kelompok IMD tidak ada bayi yang hipotermi setelah satu jam dan seluruh bayi mengalami peningkatan suhu aksila satu jam setelah kelahiran, namun pada kelompok non IMD ada empat orang bayi dengan suhu aksila dibawah $36,5^{\circ} \mathrm{C}$ dan ada delapan orang bayi yang mengalami penurunan suhu aksila setelah satu jam kelahiran. Hal ini menunjukkan bahwa IMD yang dilakukan pada bayi baru lahir mempunyai pengaruh yang sangat baik untuk dapat mempertahankan suhu pada bayi baru lahir.

Penelitian ini sejalan dengan Fransson tahun 2013 yang mendapatkan peningkatan suhu tubuh inti $0,7^{0} \mathrm{C} / \mathrm{jam}$ dengan rerata suhu rektal $36,3^{\circ} \mathrm{C}$ selama kontak kulit ke kulit ibu dan bayi. Pengaturan suhu pada bayi baru lahir normal dapat dievaluasi melalui suhu permukaan dan suhu inti, biasanya dibawah kondisi standar karena anak dipisahkan dari suhu lingkungan normalnya sendiri. Bila tidak dilakukan upaya untuk mempertahankan suhu yang hangat pada lingkungan maka dapat terjadi penurunan pada hari pertama terutama disebabkan pengaturan termoregulasi yang belum sempurna pada bayi baru lahir. Secara bertahap terjadi peningkatan metabolisme basal dan peningkatan kemampuan produksi panas selama hari pertama kelahiran. ${ }^{14}$

$$
\text { Karlsson (1996) dalam penelitiannya }
$$
mendapatkan hasil suhu rektal meningkat $0,7 \pm 0,4^{\circ} \mathrm{C}$ setelah satu jam kontak kulit. Selama satu jam kontak kulit ke kulit, suhu inti dan suhu kulit perut meningkat yang mengindikasikan keuntungan dalam pencegahan kehilangan panas. Selama bayi berada dalam bedung dan jauh dari ibu dapat terjadi penurunan suhu tubuh pada bayi baru lahir. ${ }^{15}$

Kontak kulit ke kulit harus dilanjutkan sampai akhir dari menyusu pertama untuk menunjukkan efek dan meningkatkan regulasi bayi baru lahir secara dini. $^{16}$

Menyusui secara dini selama 30 menit dapat menginduksi pembentukan panas pada bayi baru lahir. Efek termic dari menyusui dapat diperhitungkan yaitu melalui penyimpanan panas dan kemudian dipergunakan. ${ }^{11}$

Tabel 3. Pengaruh IMD Terhadap Rerata \pm SD Kehilangan Panas Konveksi

\begin{tabular}{lll}
\hline & $\begin{array}{l}\text { Rerata } \pm \text { SD J } \\
1 \text { Jam Kelahiran }\end{array}$ & $p$ \\
& $18,1 \pm 1,9$ & 0,312 \\
Non IMD & $18,8 \pm 2,4$ & \\
\hline
\end{tabular}

Tabel 3 menunjukkan analisis pengaruh IMD ter-hadap kehilangan panas konveksi. Kehilangan panas secara konveksi pada kelompok IMD lebih rendah dari pada kelompok non IMD namun secara statitik dengan teknik t-test tidak terdapat perbedaan bermakna dengan nilai $p$ value $>0,05$.

Tabel 4. Pengaruh IMD Terhadap Rerata \pm SD Kehilangan Panas Konduksi

\begin{tabular}{lll}
\hline & $\begin{array}{c}\text { Rerata } \pm \text { SD J } \\
\text { 1 Jam Kelahiran }\end{array}$ & $\boldsymbol{P}$ \\
\hline IMD & $7,1 \pm 0,7$ & \\
Non IMD & $7,4 \pm 0,9$ & 0,312 \\
\hline
\end{tabular}

Tabel 4 menunjukkan analisis pengaruh IMD ter-hadap kehilangan panas konduksi. Kehilangan panas secara konduksi pada kelompok IMD lebih rendah dari pada kelompok non IMD namun secara statitik dengan teknik t-test tidak terdapat perbedaan bermakna dengan nilai $p$ value $>0,05$.

Tabel 5. Pengaruh IMD Terhadap Rerata \pm SD Kehilangan Panas Radiasi

\begin{tabular}{lll}
\hline & $\begin{array}{c}\text { Rerata } \pm \text { SD J } \\
\text { 1 Jam Kelahiran }\end{array}$ & $\boldsymbol{P}$ \\
\hline IMD & $4,8 \pm 0,7$ & 0,557 \\
Non IMD & $5,0 \pm 0,7$ & \\
\hline
\end{tabular}


Tabel 5 menunjukkan analisis pengaruh IMD terhadap kehilangan panas radiasi. Kehilangan panas secara radiasi pada kelompok IMD lebih rendah dari pada kelompok non IMD namun secara statitik dengan teknik t-test tidak terdapat perbedaan bermakna dengan nilai $p$ value $>0,05$.

Tabel 6. Pengaruh IMD Terhadap Rerata \pm SD Total Kehilangan Panas Kering

\begin{tabular}{lll}
\hline & $\begin{array}{c}\text { Rerata } \pm \text { SD J } \\
\text { 1 Jam Kelahiran }\end{array}$ & $\boldsymbol{P}$ \\
\hline IMD & $30,1 \pm 3,4$ & 0,337 \\
Non IMD & $31,2 \pm 3,9$ & \\
\hline
\end{tabular}

Tabel 6 menunjukkan analisis pengaruh IMD terhadap total kehilangan panas pada bayi baru lahir. Kehilangan panas kering pada kelompok IMD lebih rendah dari pada kelompok non IMD namun secara statitik dengan teknik t-test tidak terdapat perbedaan bermakna dengan nilai $p$ value $>0,05$.

Tabel 7. Distribusi Rerata \pm SD Suhu Kulit Kelompok IMD dan non IMD

\begin{tabular}{lll}
\hline Karakteristik & $\begin{array}{c}\text { Setelah lahir } \\
\text { Rerata } \pm \text { SD J }\end{array}$ & $\begin{array}{c}\text { 1 Jam Kelahiran } \\
\text { Rerata } \pm \text { SD J }\end{array}$ \\
\hline Suhu Kulit & & \\
IMD & $36,4 \pm 0,3$ & $37,2 \pm 0,7$ \\
Non IMD & $36,5 \pm 0,4$ & $37 \pm 0,3$ \\
\hline
\end{tabular}

Tabel 7 menunjukkan distribusi rerata suhu kulit kelompok IMD setelah kelahiran adalah 36,4士 $0,3^{0} \mathrm{C}$ mengalami peningkatan menjadi $37,2 \pm 0,7^{0} \mathrm{C}$ setelah IMD. Pada kelompok non IMD rerata suhu kulit setelah lahir adalah $36,5^{\circ} \mathrm{C}$ mengalami peningkatan menjadi $37 \pm 0,3^{0} \mathrm{C}$.

\section{PEMBAHASAN}

Pada penelitian ini didapatkan bahwa tidak terdapat perbedaan yang bermakna pada kelompok IMD dan non IMD terhadap kehilangan rerata panas kering pada bayi satu jam kelahiran atau setelah IMD, baik kehilangan panas secara konveksi, konduksi dan radiasi. Namun rerata kehilangan panas sesudah IMD lebih kecil pada kelompok IMD dari pada kehilangan panas satu jam kelahiran pada kelompok non IMD. Secara statistik dengan teknik t-test diperoleh nilai $p$ value $>0,05$. Hal ini kemungkinan dipengaruhi oleh suhu udara, suhu dinding, kecepatan angin dan insulasi pakaian yang hampir sama pada kedua kelompok responden. Suhu ruangan bersalin selalu diupayakan sehangat mungkin dan penelitian ini diperoleh rerata suhu ruangan bersalin sekitar $30^{\circ} \mathrm{C}$ demikian halnya dengan suhu dinding. Setelah lahir bayi juga mendapat perlakuan yang sama yaitu segera dikeringkan dan dibungkus dengan bahan yang sama dan jumlah lapisan yang sama. Bedanya kelompok bayi dengan IMD ditutup dari atas punggung dengan kontak kulit ke kulit ibu, sedangkan bayi tanpa IMD langsung dibedung tanpa dilakukan kontak kulit ke kulit. Kekurangan dalam penelitian ini adalah tidak dilakukannya kontak kulit tangan ibu ke badan bayi, dimana tangan ibu hanya memeluk bayinya dari luar kain penutup bayi.

Pada saat lahir suhu kulit kelompok non IMD lebih tinggi dari kelompok IMD yaitu $36,5 \pm 0,4^{\circ} \mathrm{C}$ dan meningkat $0,5^{\circ} \mathrm{C}$ selama satu jam kelahiran. Rerata suhu kulit kelompok IMD lebih rendah dibandingkan kelompok non IMD yaitu $36,4 \pm 0,3^{0} \mathrm{C}$ namun mengalami peningkatan yang lebih tinggi dibandingkan kelompok non IMD yaitu $0,8^{\circ} \mathrm{C}$.

Suhu kulit berbeda dengan suhu inti, dapat naik dan turun sesuai dengan suhu lingkungan. Suhu inti cenderung dipertahankan selalu konstan. Suhu kulit merupakan suhu yang penting apabila merujuk pada kemampuan kulit untuk melepaskan panas ke lingkungan, sehingga bila terjadi perubahan pada suhu lingkungan eksternal maka tubuh akan melakukan pengaturan untuk mempertahankan keseimbangan suhu. $^{17}$

Menurunkan kehilangan panas sangat berhubungan dengan upaya untuk bertahan hidup pada bayi baru lahir. Selama periode kontak kulit ke kulit, suhu inti dan suhu kulit perut meningkat yang mengindikasikan keuntungan dalam pencegahan kehilangan panas. Selama bayi berada dalam bedung dan jauh dari ibu terjadi penurunan suhu tubuh dan peningkatan kehilangan panas mendekati kompensasi bayi baru lahir sekitar $70 \mathrm{~W} / \mathrm{m}^{2}$. Bedung yang terlalu ketat dan kuat akan membuat bayi lebih dingin karena tidak dapat mempertahankan posisi flexi. ${ }^{12,15}$

Kontak kulit ke kulit pada bayi baru lahir sama efektifnya dengan pemanas bayi yang dapat 
mencegah kehilangan panas pada bayi baru lahir aterm. ${ }^{16}$

Penelitian Fransson tahun 2013 melaporkan bahwa terdapat peningkatan suhu kulit kaki tertinggi pada jam pertama bayi baru lahir selama bayi diletakkan dekat dengan ibu. Pada saat ini suhu kulit perut juga lebih tinggi dibandingkan rerata suhu kulit perut, dan perbedaan suhu kulit perut dan kaki pada saat ini hanya sedikit. Suhu kulit kaki terendah didapati pada saat bayi berada dalam pakaian, selama periode ini suhu kulit perut lebih rendah dibandingkan rerata suhu kulit perut dan perbedaan suhu bayi juga besar. Hal ini sama ditemukan baik pada hari pertama dan kedua. $^{14}$

Kehilangan panas konveksi dapat terjadi pada bayi baru lahir yang disebabkan oleh jumlah luas permukaan tubuh yang memiliki kontak dengan suhu udara dan secara signifikan dapat dicegah atau diturunkan dengan membungkus bayi. Pembungkus bayi akan menjadi barier atau penahan panas dari udara yang bersifat sebagai insulasi untuk mencegah kehilangan panas dari lapisan kulit bayi yang tipis dan juga memberi kehangatan kepada bayi secara konduksi, namun hanya sebagian merubah suhu permukaan kulit pada suhu yang stabil yaitu sekitar $+0,2^{0} \mathrm{C}^{14,18}$

Suhu ruangan yang hangat dan pembungkus bayi berhubungan dengan suhu penerimaan bayi yang lebih tinggi. Kehilangan panas pada bayi baru lahir dapat dicegah dengan segera mengeringkan, membungkus bayi baru lahir, menyediakan ruangan persalinan yang hangat dan suhu lingkungan yang ideal sekitar $26^{\circ} \mathrm{C}^{18}$

Tindakan seperti membuka baju bayi, kontak kulit dengan udara dan menyabuni bayi saat mandi berhubungan dengan kehilangan panas secara radiasi, konveksi dan evaporasi. Memandikan bayi baru lahir sebaiknya ditunda setidaknya enam jam setelah lahir. Memandikan bayi juga tidak harus dilakukan setiap hari, bahkan memandikan bayi setiap hari dapat mengakibatkan kulit bayi kering. ${ }^{19,20}$ Untuk itu upaya seperti inisiasi menyusu dini merupakan hal yang penting untuk dapat mengurangi kehilangan panas pada tubuh bayi baru lahir.

\section{KESIMPULAN}

Terdapat pengaruh inisiasi menyusu dini terhadap suhu aksila pada bayi setelah satu jam kelahiran. Kehilangan panas kering lebih rendah pada kelompok IMD dibandingkan dengan kelompok non IMD tetapi tidak bermakna secara statistik.

\section{UCAPAN TERIMA KASIH}

Penulis mengucapkan terima kasih kepada Poltekkes Kemenkes Medan atas kesempatan yang diberikan untuk melanjutkan pendidikan. Kepada RS Tk. III Dr. Reksodiwiryo Padang sebagai tempat penelitian atas fasilitas yang telah diberikan. Kepada Prof. Dr. dr. Eryati Darwin. PA(K) dan dr. Eny Yantri, SpA, sebagai pembimbing atas masukan dan bimbingan dalam menyelesaikan tesis ini.

\section{DAFTAR PUSTAKA}

1. Kliegman RM. Janin dan bayi neonatus. Dalam: IImu Kesehatan Anak Nelson. Edisi ke-15, vol;1, Wahab AS, editor edisi bahasa Indonesia. Jakarta: EGC; 2012. hlm. 535-41.

2. Onalo R. Neonatal hypothermia in subSaharan Africa: a review. Nigerian Journal of Clinical Practice.2013;16(2):129-38.

3. JNPK-KR. Paket pelatihan pelayanan obstetri neonatal emergensi dasar (PONED). Jakarta; 2008.

4. Yunanto A. Termoregulasi. Dalam Kosim MS, Yunanto A, Dewi R, Sarosa GI, Usman A, editor (penyunting). Buku Ajar Neonatologi. Jakarta: IDAI; 2010. hlm. 89-102.

5. WHO. The world health statistics 2011 (diunduh 19 Agustus 2013). Tersedia dari: URL: HYPERLINK http://www.who.int

6. Farrel P, Sittlington N. Bayi pada saat lahir. Dalam: Fraser DM, Cooper MA, editor (penyunting). Buku Ajar Bidan Myles. Edisi ke-14. Jakarta: EGC; 2009. hlm. 690-3.

7. WHO. Newborn care at birth (diunduh 19 Agustus 2013). Tersedia dari: URL: HYPERLINK http: //www.who.int/maternal child adolescent/ topics/ newborn/café at birth/en/ index.html\#

8. WHO. Breastfeeding-early initiation (diunduh 19 
Agustus 2013). Tersedia dari: URL: HYPERLINK http://www.who.int/elena/titles/early breastfeeding/ en/eLENA

9. Karlsson $H$. Skin to skin care: heat balance. Sweden. Archives if disease in childhood. 1996; (75):F130-F2

10. Gabriel JS. Fisika kedokteran. Jakarta: EGC; 1996. hlm. 124-29.

11. Alexandra AK, Nelson RA, Bell ER, Cesar AE. Use of infrared thermographic calorimetry to determine energy expenditure in preterm infants. Am J Clin Nutr. 2000;(71):969.

12. Waldron S, Mackinnon R. Neonatal thermoregulation. Infant. 2007;(3):101-4.

13. Elabbassi EB, Bach V, Makki M, Delanaud S, Telliez F, Leke A, et al. Assessment of dryheat exchanges in newborns: influence of body position andclothing in SIDS. J Appl Physiol.2001;(91):51-6

14. Fransson AL, Karlsson $\mathrm{H}$, Nilsson K. Temperature variation in newborn babies: importance of physical contact with the mother. Arch dis child fetal neonatal. 2005;(90): F500-F4.

15. Karlsson H. Skin to skin care: heat balance. Sweden: Archives if disease in childhood. 1996; (75):F130-F2.

16. Moore ER, Anderson GC, Bergman N, Dowswell T. Early skin-to-skin contact for mothers and their healthy newborn infants (review). The Cochrane Library 2012.(5).

17. Johnson R, Taylor W. Buku ajar praktik kebidanan: Kurnianingsih S, Ester $\mathrm{M}$, editor edisi bahasa Indonesia. Jakarta; EGC: 2005. hlm. 29-45.

18. Knobel RB, Wimmer JE, Holbert D. heat loss prevention for preterm infants in the delivery room. Journal of Perinatology. 2005;(25):304-8.

19. Takayama JI, Teng W, Uyemoto J, Newman TB, Pantell $\mathrm{RH}$. Body temperature of newborns: what is normal? Clin Pediatr. 2000;39: 503.

20.JNPK-KR/POGI. Asuhan persalinan normal \& Inisiasi menyusui dini: Buku Acuan dan Panduan. Edisi ke-3. Jakarta: Jaringan Nasional Pelatihan Klinik; 2012. 